\title{
Phytochemical Screening and Antiprotozoal Effects of the Methanolic Berberis Vulgaris and Acetonic Rhus Coriaria Extracts
}

\author{
Gaber El-Saber Batiha ${ }^{1,2, *,+}$, Amany Magdy Beshbishy ${ }^{1, \dagger}{ }^{+}$, Oluyomi Stephen Adeyemi ${ }^{3}{ }^{\circ}$, \\ Eman Hassan Nadwa ${ }^{4,5}$ (D), Eman kadry Mohamed Rashwan ${ }^{6,7}$, Luay M. Alkazmi ${ }^{8}$, \\ Amr A. Elkelish ${ }^{9}$ (i) and Ikuo Igarashi ${ }^{1}$
}

1 National Research Center for Protozoan Diseases, Obihiro University of Agriculture and Veterinary Medicine, Nishi 2-13, Inada-cho, Obihiro 080-8555, Hokkaido, Japan; amanimagdi2008@gmail.com (A.M.B.); igarcpmi@obihiro.ac.jp (I.I.)

2 Department of Pharmacology and Therapeutics, Faculty of Veterinary Medicine, Damanhour University, Damanhour 22511, AlBeheira, Egypt

3 Department of Biochemistry, Medicinal Biochemistry, Nanomedicine and Toxicology Laboratory, Landmark University, Omu-Aran 251101, Kwara State, Nigeria; oluyomiadeyemi@gmail.com

4 Department of Pharmacology and Therapeutics, College of Medicine, Jouf University, Sakaka 72345, Saudi Arabia; emanhassannadwa@yahoo.co.uk

5 Department of Medical Pharmacology, Faculty of Medicine, Cairo University, Giza 12613, Egypt

6 Department of Physiology, College of Medicine, Al-Azhar University, Assuit 71524, Egypt; dremanrashwan2020@gmail.com

7 Department of Physiology, College of Medicine, Jouf University, Sakaka 42421, Saudi Arabia

8 Biology Department, Faculty of Applied Sciences, Umm Al-Qura University, Makkah 21955, Saudi Arabia; lmalkazmi@uqu.edu.sa

9 Department of Botany, Faculty of Science, Suez Canal University, Ismailia 41522, Egypt; amr.elkelish@science.suez.edu.eg

* Correspondence: dr_gaber_batiha@vetmed.dmu.edu.eg or gaberbatiha@gmail.com; Tel.: +20-45-271-6024; Fax: +20-45-271-6024

+ These authors contributed equally to this work.

Received: 17 December 2019; Accepted: 25 January 2020; Published: 27 January 2020

\begin{abstract}
Berberis vulgaris (B. vulgaris) and Rhus coriaria (R. coriaria) have been documented to have various pharmacologic activities. The current study assessed the in vitro as well as in vivo inhibitory efficacy of a methanolic extract of B. vulgaris (MEBV) and an acetone extract of $R$. coriaria (AERC) on six species of piroplasm parasites. The drug-exposure viability assay was tested on three different cell lines, namely mouse embryonic fibroblast (NIH/3T3), Madin-Darby bovine kidney (MDBK) and human foreskin fibroblast (HFF) cells. Qualitative phytochemical estimation revealed that both extracts containing alkaloid, tannin, saponins and terpenoids and significant amounts of flavonoids and polyphenols. The GC-MS analysis of MEBV and AERC revealed the existence of 27 and 20 phytochemical compounds, respectively. MEBV and AERC restricted the multiplication of Babesia (B.) bovis, B. bigemina, B. divergens, B. caballi, and Theileria (T.) equi at the half-maximal inhibitory concentration $\left(\mathrm{IC}_{50}\right)$ of $0.84 \pm 0.2,0.81 \pm 0.3,4.1 \pm 0.9,0.35 \pm 0.1$ and $0.68 \pm 0.1 \mu \mathrm{g} / \mathrm{mL}$ and $85.7 \pm 3.1$, $60 \pm 8.5,90 \pm 3.7,85.7 \pm 2.1$ and $78 \pm 2.1 \mu \mathrm{g} / \mathrm{mL}$, respectively. In the cytotoxicity assay, MEBV and AERC inhibited MDBK, NIH/3T3 and HFF cells with half-maximal effective concentrations $\left(\mathrm{EC}_{50}\right)$ of $695.7 \pm 24.9,931 \pm 44.9,>1500 \mu \mathrm{g} / \mathrm{mL}$ and $737.7 \pm 17.4,>1500$ and $>1500 \mu \mathrm{g} / \mathrm{mL}$, respectively. The experiments in mice showed that MEBV and AERC prohibited B. microti multiplication at $150 \mathrm{mg} / \mathrm{kg}$ by $66.7 \%$ and $70 \%$, respectively. These results indicate the prospects of these extracts as drug candidates for piroplasmosis treatment following additional studies in some clinical cases.
\end{abstract}


Keywords: Berberis vulgaris; Rhus coriaria; Babesia; Theileria; drug candidates; clinical studies; pharmacological activities

\section{Introduction}

Piroplasmosis is the exhausting ailment caused by hematotropic piroplasm parasites [1]. Up to date, numerous drugs have been used for the treatment of piroplasmosis infections [2,3]. For instance, clindamycin-quinine, pentamidine-cotrimoxazole and atovaquone (ATV) combination with either azithromycin or proguanil have been reported for zoonotic babesiosis treatment, yet some investigations reported Babesia (B.) gibsoni resistance towards ATV [4,5]. Additionally, diminazene aceturate (DMA), oxytetracycline and imidocarb dipropionate, the treatment choices for bovine and equine piroplasmosis showed limited efficacy and there have been reported of unwanted symptoms and the emergence of resistant parasites [6]. In general, advances in piroplasmosis treatment is vital for improving disease treatment and tick control [7,8]. Several antipiroplasmic molecules and drug targets were identified, presenting an alternative choice for disease control [4-6,9-11]. The extensive socio-economic and welfare effects of bovine and equine piroplasmosis on animals and human babesiosis on humans have sustained the demand for pharmaceutical advancements to develop novel drug candidates.

Herbal remedies have been attracting attention as a prospective alternative resource of therapy for diverse diseases across many nations [12,13]. In recent decades, medicinal plants have been gaining wider acceptance due to the perception that these plants being natural products have lesser side effects and improved efficacy than their synthetic counterparts [9,12]. Many plant species have been reported to have pharmacological activities attributable to their phytoconstituents such as glycosides, saponins, flavonoids, steroids, tannins, alkaloids, terpenes, etc. [11,14].

Berberis vulgaris L. Sp. Pl. 1: 330 (-331) (1753) (B. vulgaris), in the genus Berberis (family Berberidaceae), is the most widely known Berberis that is indigenous to semi-tropical areas in Africa, Asia, Europe, North America, and South America and it is used mainly as food [15]. Pharmacologically, B. vulgaris have been documented to have several therapeutic properties, including anti-inflammatory, sedative, antipyretic, antiemetic, antioxidant, anti-cholinergic, anti-arrhythmic, anti-leishmaniasis, antimicrobial, and anti-malarial [16-18]. The phytochemical examination showed the existence of several molecules such as phenolic compounds, tannins, sterols, vitamins (vitamins $\mathrm{A}$ and $\mathrm{C}$ ), protein, carotenoid, anthocyanin, dextrose, malic acid, fructose, citric acid, pectin, tartaric acid, resin, elements (calcium, iron, and potassium, zinc, copper, and manganese), alkaloids and triterpenes [18]. Berberine and berbamine are the most valuable alkaloids exhibiting a variety of activities, such as hypoglycemia, anti-inflammatory, hypotensive, antioxidant, and hypolipidemic properties [19,20]. Previous studies documented the berberine significance in the treatment of schistosomiasis disease incomparable to the anti-schistosomiasis drug; praziquantel and they reported the beneficial effects of berberine on Schistosoma (S.) mansoni by inducing oxidative stress which may be the main cause of its antioxidant activity [21]. Additionally, berberine has the same effect in Plasmodium (P.) chabaudi through its anti-inflammatory effect as it acts by reducing the inflammatory response induced by the parasite and increasing the activities of alanine and aspartate transaminases [22,23]. Interestingly, recent reports documented the potent antiparasitic effect of $B$. vulgaris as well as berberine against Trichomonas vaginalis, Giardia lamblia, Entamoeba histolytica, and some Leishmania (L.) spp. For instance, Mahmoudvand et al. [20] revealed that B. vulgaris methanolic extract showed potent leishmanicidal activity against L. infantum and L. tropica $\left(\mathrm{IC}_{50}=4.83 \mu \mathrm{g} / \mathrm{mL}\right)$ in vitro. Additionally, Vennerstrom et al. [24] reported that berberine alone demonstrated a potential leishmanicidal effect with an $\mathrm{IC}_{50}$ value of $7.1 \mu \mathrm{M}$ and ranging from 2.1 to $26.6 \mu \mathrm{g} / \mathrm{mL}$ against L. donovani, L. tropica, and L. major promastigotes, respectively. The root bark extract of $B$. vulgaris was used to prepare a lotion formula which led to good suppression effects in mice with $90 \%$ recovery from cutaneous leishmaniasis $[25,26]$. 
Rhus coriaria L., Sp. Pl. 1: 265 (1753) (R. coriaria), of the genus Rhus that is consisting of more than 250 kinds of flowering plants of the Anacardiaceae family, which is widely reported as a medicinal herb for wound healing in addition to its common use as a spice in the Mediterranean and the Middle East [27]. Interestingly, $R$. coriaria contains a set of biologically active compounds including volatile substances, flavonoids, tannins, $\alpha$ pinene, cembrene $\beta$-caryophyllene, oxygenated terpenes ( $\beta$-caryophyllene alcohol, hexahydrofarnesylacetone, $\alpha$-terpineol, carvacrol, farnesyl acetone, aliphatic aldehydes), 2,3,6-trihydroxy-7-hydroxymethylene xanthone-1-carboxylic acid, $\beta$-sitosterol$\beta$-D-glucoside, 2-methoxy-4-hydroxy-7-methyl-3-O- $\beta$-D-glucopyranosyl xanthone-1,8-dicarboxylic acid, 2,3-dihydroxy-7-methyl xanthone, tannins, myricetin and organic acids (malic and citric acids) that exhibit many pharmacological activities such as anti-gastric, antidiarrheal, antispasmodic, antidysenteric, hepatoprotective, antihepatotoxic, heptatonic, astringent, protisticide, analgesic, anti-inflammatory, antioxidant, antiviral, antibacterial and antimalarial [28-30]. Moreover, Gathirwa et al. [31] reported the broad-spectrum antibacterial effect of Rhus organic solvent extracts toward acid-fast and spore-forming, Gram-positive and Gram-negative bacteria, and this activity may be attributed to the presence of tannin [30,31]. Pal Singh et al. [32] documented the antioxidant, antiobesity, antiasthmatic, hepatoprotective and anticancer activity of gallic acid, the main active principle of $R$. coriaria.

Although these plants have been reported for various pharmacological values, there is no evidence on the antipiroplasmic activity of B. vulgaris and R. coriaria crude extracts. Thus, the current study examined the effectiveness of a methanolic extract of $B$. vulgaris (MEBV) and an acetone extract of R. coriaria (AERC) on the multiplication of Theileria (T.) equi, B. bigemina, B. bovis, B. caballi and B. divergens using the in vitro fluorescence assay and their chemotherapy prospects against $B$. microti-infected mice.

\section{Results}

\subsection{Plant Extraction, Phytochemical and Total Phenolic and Flavonoid Contents Evaluation of MEBV and AERC Extracts}

The yield percentage of the MEBV and AERC were 7.31 and $8.06 \% w / w$ dry matter and dark in color. Preliminary examination of MEBV pointed to the existence of different phytoconstituents such as tannins, saponins, alkaloids, and terpenoids, while AERC contains saponins, alkaloids, and terpenoids that may be responsible for their pharmacological activities. Moreover, considerable amounts of polyphenols and flavonoid contents were observed in MEBV and AERC. Notably, MEBV $(63.2 \pm 4.2 \mathrm{mg}$ of GAE/g DW) showed the highest total phenolic content followed by AERC (59.9 $\pm 9.4 \mathrm{mg}$ of GAE/g DW). Moreover, AERC (42.9 $\pm 5.1 \mathrm{mg}$ of CAE/g DW) had the highest total flavonoid content followed by MEBV (39. $2 \pm 4.7 \mathrm{mg}$ of CAE/g DW).

\subsection{Gas Chromatography-Mass Spectrometry (GC-MS) Analysis}

The GC-MS analysis of MEBV and AERC revealed the existence of 27 and 20 phytochemical compounds, respectively. The identified chemical composition of MEBV is shown in Table 1 and represented 27 compounds, while the identified chemical composition of AERC is shown in Table 2 and represented 20 compounds. The phytochemical compounds' identification was established on the basis of the peak area, and retention time. The active principles with their retention time (RT) and percentage of peak area (\%) are expressed in Figures S1 and S2. 
Table 1. The chemical composition of MEBV by GC-MS.

\begin{tabular}{|c|c|c|c|c|c|}
\hline Peak & R.t & Name & Area $(\%)$ & $\begin{array}{l}\text { Molecular } \\
\text { Weight }\end{array}$ & $\begin{array}{l}\text { Molecular } \\
\text { Formula }\end{array}$ \\
\hline 1 & 8.71 & 2-Pentanone, 4-Hydroxy-4-Methyl- & 6.43 & 116 & $\mathrm{C}_{6} \mathrm{H}_{12} \mathrm{O}_{2}$ \\
\hline 2 & 10.30 & Propanal, 3-Ethoxy- & 0.50 & 102 & $\mathrm{C}_{5} \mathrm{H}_{10} \mathrm{O}_{2}$ \\
\hline 3 & 13.83 & trans-2-Pentenoic acid & 0.52 & 100 & $\mathrm{C}_{5} \mathrm{H}_{8} \mathrm{O}_{2}$ \\
\hline 4 & 14.99 & Acetic acid, Phenyl ester & 0.22 & 136 & $\mathrm{C}_{8} \mathrm{H}_{8} \mathrm{O}_{2}$ \\
\hline 5 & 15.07 & 6-Nonynoic acid & 0.37 & 154 & $\mathrm{C}_{9} \mathrm{H}_{14} \mathrm{O}_{2}$ \\
\hline 6 & 16.99 & Benzyl alcohol & 1.22 & 108 & $\mathrm{C}_{7} \mathrm{H}_{8} \mathrm{O}$ \\
\hline 7 & 18.11 & Benzene, 1,3,5-Trimethyl- & 0.37 & 120 & C9H12 \\
\hline 8 & 18.57 & Phenol, 2-Methoxy & 1.24 & 124 & $\mathrm{C}_{7} \mathrm{H}_{8} \mathrm{O}_{2}$ \\
\hline 9 & 19.94 & Phenylethyl Alcohol & 9.58 & 122 & $\mathrm{C}_{8} \mathrm{H}_{10} \mathrm{O}$ \\
\hline 10 & 20.68 & Ribitol & 0.90 & 152 & $\mathrm{C}_{5} \mathrm{H}_{12} \mathrm{O}_{5}$ \\
\hline 11 & 24.48 & 3-(2-Hydroxyphenyl) acrylic acid & 15.55 & 164 & $\mathrm{C}_{9} \mathrm{H}_{8} \mathrm{O}_{3}$ \\
\hline 12 & 25.24 & Octadecanoic acid, 3-hydroxy-, methyl ester & 2.66 & 314 & $\mathrm{C}_{19} \mathrm{H}_{38} \mathrm{O}_{3}$ \\
\hline 13 & 25.74 & $\alpha$-Ylangene & 0.39 & 204 & $\mathrm{C}_{15} \mathrm{H}_{24}$ \\
\hline 14 & 26.70 & 7,10-Pentadecadiynoic acid & 0.65 & 234 & $\mathrm{C}_{15} \mathrm{H}_{22} \mathrm{O}_{2}$ \\
\hline 15 & 27.01 & 2-Methoxy-4-vinylphenol & 8.41 & 150 & $\mathrm{C}_{9} \mathrm{H}_{10} \mathrm{O}_{2}$ \\
\hline 16 & 27.49 & $\alpha$-Longipinene & 1.27 & 204 & $\mathrm{C}_{15} \mathrm{H}_{24}$ \\
\hline 17 & 27.74 & 2-Propen-1-Ol, 3-Phenyl & 10.16 & 134 & $\mathrm{C}_{9} \mathrm{H}_{10} \mathrm{O}$ \\
\hline 18 & 29.84 & $\alpha$-Curcumene & 13.27 & 204 & $\mathrm{C}_{15} \mathrm{H}_{24}$ \\
\hline 19 & 30.08 & trans-Sesquisabinene hydrate & 2.50 & 222 & $\mathrm{C}_{15} \mathrm{H}_{26} \mathrm{O}$ \\
\hline 20 & 30.21 & $\alpha$-Bulnesene & 2.41 & 204 & $\mathrm{C}_{15} \mathrm{H}_{24}$ \\
\hline 21 & 30.67 & Sesquicineole & 1.07 & 222 & $\mathrm{C}_{15} \mathrm{H}_{26} \mathrm{O}$ \\
\hline 22 & 31.41 & 2-Propen-1-Ol, 3-Phenyl-, Acetate & 3.94 & 176 & $\mathrm{C}_{11} \mathrm{H}_{12} \mathrm{O}_{2}$ \\
\hline 23 & 31.69 & Aromadendrene oxide & 2.27 & 220 & $\mathrm{C}_{15} \mathrm{H}_{24} \mathrm{O}$ \\
\hline 24 & 33.17 & Methyl 5,7-hexadecadiynoate & 3.22 & 262 & $\mathrm{C}_{17} \mathrm{H}_{26} \mathrm{O}_{2}$ \\
\hline 25 & 34.21 & Guaiol & 5.93 & 222 & $\mathrm{C}_{15} \mathrm{H}_{26} \mathrm{O}$ \\
\hline 26 & 35.56 & $\alpha$-Guaiene & 2.54 & 204 & $\mathrm{C}_{15} \mathrm{H}_{24}$ \\
\hline 27 & 35.76 & cis-5,8,11,14,17-Eicosapentaenoic acid & 1.30 & 302 & $\mathrm{C}_{20} \mathrm{H}_{30} \mathrm{O}_{2}$ \\
\hline
\end{tabular}

R.t, retention time (min).

Table 2. The chemical composition of AERC by GC-MS.

\begin{tabular}{|c|c|c|c|c|c|}
\hline Peak & R.t & Name & Area $(\%)$ & $\begin{array}{c}\text { Molecular } \\
\text { Weight }\end{array}$ & $\begin{array}{c}\text { Molecular } \\
\text { Formula }\end{array}$ \\
\hline 1 & 8.66 & 2-Pentanone, 4-Hydroxy-4-Methyl- & 8.87 & 116 & $\mathrm{C}_{6} \mathrm{H}_{12} \mathrm{O}_{2}$ \\
\hline 2 & 12.15 & 2-Butenedioic acid & 21 & 116 & $\mathrm{C}_{4} \mathrm{H}_{4} \mathrm{O}_{4}$ \\
\hline 3 & 14.34 & 3-Thujanol & 1.14 & 154 & $\mathrm{C}_{10} \mathrm{H}_{18} \mathrm{O}$ \\
\hline 4 & 14.93 & 4-Heptenal & 1.20 & 112 & $\mathrm{C}_{7} \mathrm{H}_{12} \mathrm{O}$ \\
\hline 5 & 15.11 & 2,4-Heptadienal, $(E, E)$ & 2.12 & 110 & $\mathrm{C}_{7} \mathrm{H}_{10} \mathrm{O}$ \\
\hline 6 & 17.00 & 2-Nonen-1-ol, $(E)$ & 1.00 & 142 & $\mathrm{C}_{9} \mathrm{H}_{18} \mathrm{O}$ \\
\hline 7 & 19.96 & 4-Penten-2-Ol, 3-Methyl- & 0.90 & 100 & $\mathrm{C}_{6} \mathrm{H}_{12} \mathrm{O}$ \\
\hline 8 & 23.28 & 2-Decenal, $(E)$ - & 1.69 & 154 & $\mathrm{C}_{10} \mathrm{H}_{18} \mathrm{O}$ \\
\hline 9 & 24.03 & Benzaldehyde, 4-(1-methylethyl)- & 9.33 & 148 & $\mathrm{C}_{10} \mathrm{H}_{12} \mathrm{O}$ \\
\hline 10 & 25.31 & $\alpha$-Ylangene & 0.95 & 204 & $\mathrm{C}_{15} \mathrm{H}_{24}$ \\
\hline 11 & 25.58 & 1,4-p-Menthadien-7-al & 10.07 & 150 & $\mathrm{C}_{10} \mathrm{H}_{14} \mathrm{O}$ \\
\hline 12 & 25.90 & 2,4-Decadienal, $(E, E)-$ & 1.42 & 152 & $\mathrm{C}_{10} \mathrm{H}_{16} \mathrm{O}$ \\
\hline 13 & 26.68 & 2-Undecenal, E- & 2.34 & 168 & $\mathrm{C}_{11} \mathrm{H}_{20} \mathrm{O}$ \\
\hline 14 & 27.34 & Caryophyllene & 2.05 & 204 & $\mathrm{C}_{15} \mathrm{H}_{24}$ \\
\hline 15 & 29.50 & Methyleugenol & 3.60 & 178 & $\mathrm{C}_{11} \mathrm{H}_{14} \mathrm{O}_{2}$ \\
\hline 16 & 29.78 & Benzene,1-(1,5-Dimethyl-4-Hexenyl)-4-Methyl- & 1.55 & 202 & $\mathrm{C}_{15} \mathrm{H}_{22}$ \\
\hline 17 & 30.06 & 2,6,10-Dodecatrien-1-ol,3,7,11-trimethyl- & 0.70 & 222 & $\mathrm{C}_{15} \mathrm{H}_{26} \mathrm{O}$ \\
\hline 18 & 30.82 & 7-epi-cis-Sesquisabinene hydrate & 3.47 & 222 & $\mathrm{C}_{15} \mathrm{H}_{26} \mathrm{O}$ \\
\hline 19 & 31.84 & 1,2,3-Benzenetriol (Pyrogallic acid) & 21.04 & 126 & $\mathrm{C}_{6} \mathrm{H}_{6} \mathrm{O}_{3}$ \\
\hline 20 & 34.70 & cis-Z- $\alpha$-Bisabolene epoxide & 2.88 & 220 & $\mathrm{C}_{15} \mathrm{H}_{24} \mathrm{O}$ \\
\hline
\end{tabular}




\subsection{Growth-Inhibition Efficacy of MEBV and AERC In Vitro}

The preliminary evaluation of MEBV and AERC was performed to detect their efficacy on the host red blood cells (RBCs)prior to the subculture of T. equi and B. bovis. The parasite proliferation did not significantly differ between RBCs treated with either MEBV or AERC and the untreated one for both species. For the growth-inhibitory effect, MEBV (Figure 1) and AERC (Figure 2) affected the multiplication of all treated species in a dose-related manner.

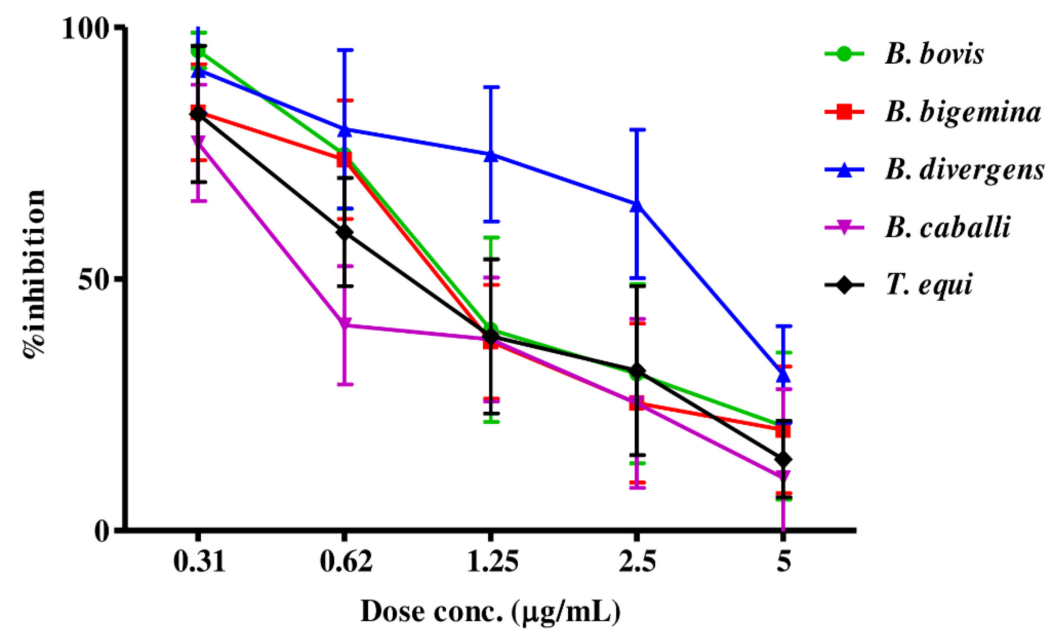

Figure 1. Dose-response curves of MEBV against Babesia and Theileria parasites in vitro. The curves showing the correlation between the percentage of inhibition and the concentration of MEBV $(\mu \mathrm{g} / \mathrm{mL})$ on B. bovis, B. bigemina, B. divergens, B. caballi and T. equi. The values obtained from three separate trials were used to determine the $\mathrm{IC}_{50}$ 's using the non-linear regression (curve fit analysis) in GraphPad Prism software (GraphPad Software Inc., La Jolla, CA, USA).

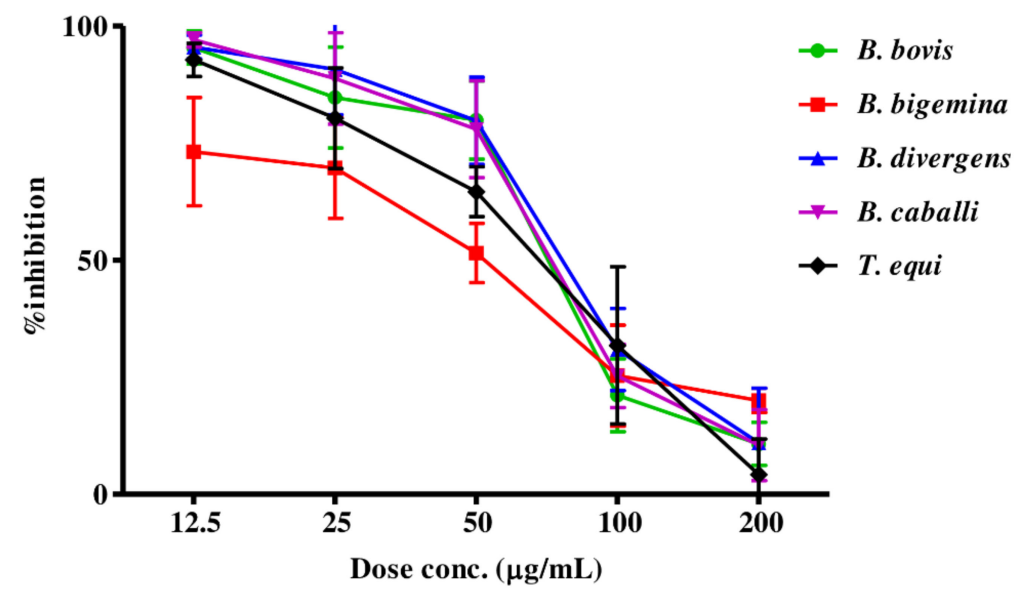

Figure 2. Dose-response curves of AERC against Babesia and Theileria parasites in vitro. The curves showing the correlation between the percentage of inhibition and the concentration of AERC $(\mu \mathrm{g} / \mathrm{mL})$ on $B$. bovis, B. bigemina, B. divergens, B. caballi and T. equi. The values obtained from three separate trials were used to determine the $\mathrm{IC}_{50}$ 's using the non-linear regression (curve fit analysis) in GraphPad Prism software.

MEBV and AERC suppressed B. bovis, B. bigemina, B. divergens, B. caballi, and T. equi multiplication with $\mathrm{IC}_{50} \mathrm{~s}$ shown in Table 3. For the reference antibabesial drugs, DMA, ATV and clofazimine (CLF) restricted B. bovis, B. bigemina, B. divergens, B. caballi, and T. equi multiplication with $\mathrm{IC}_{50} \mathrm{~s}$ shown in Table S2. 
Table 3. $\mathrm{IC}_{50}$ and selective index values of MEBV and AERC.

\begin{tabular}{|c|c|c|c|c|c|c|c|c|}
\hline \multirow{2}{*}{ Crude Extracts } & \multirow{2}{*}{ Parasites } & \multirow{2}{*}{$\mathrm{IC}_{50}(\mu \mathrm{g} / \mathrm{mL})^{\mathrm{a}}$} & \multicolumn{3}{|c|}{$\mathrm{EC}_{50}(\mu \mathrm{g} / \mathrm{mL})^{b}$} & \multicolumn{3}{|c|}{ Selective Indices $^{c}$} \\
\hline & & & MDBK & $\mathrm{NIH} / 3 \mathrm{~T} 3$ & HFF & MDBK & NIH/3T3 & HFF \\
\hline \multirow{5}{*}{ MEBV } & B. bovis & $0.84 \pm 0.2$ & $695.7 \pm 24.9$ & $931 \pm 44.9$ & $>1500$ & 828.2 & 1108.3 & $>1785.7$ \\
\hline & B. bigemina & $0.81 \pm 0.3$ & & & & 858.9 & 1149.3 & $>1851.9$ \\
\hline & B. divergens & $4.1 \pm 0.9$ & & & & 169.7 & 227.1 & $>365.9$ \\
\hline & B. caballi & $0.35 \pm 0.1$ & & & & 1987.7 & 2660 & $>4285.7$ \\
\hline & T. equi & $0.68 \pm 0.1$ & & & & 1023.1 & 1369.1 & $>2205.9$ \\
\hline \multirow{5}{*}{ AERC } & B. bovis & $85.7 \pm 3.1$ & $737.7 \pm 17.4$ & $>1500$ & $>1500$ & 8.6 & $>17.5$ & $>17.5$ \\
\hline & B. bigemina & $55.7 \pm 2.7$ & & & & 13.2 & $>26.9$ & $>26.9$ \\
\hline & B. divergens & $90 \pm 3.7$ & & & & 8.2 & $>16.7$ & $>16.7$ \\
\hline & B. caballi & $85.7 \pm 2.1$ & & & & 8.6 & $>17.5$ & $>17.5$ \\
\hline & T. equi & $78 \pm 2.1$ & & & & 9.5 & $>19.2$ & $>19.2$ \\
\hline
\end{tabular}

${ }^{a}$ Half-maximal inhibitory concentration of extracts on piroplasm parasites in vitro. ${ }^{b}$ Half-maximal effective concentration of extracts on the tested cell lines. The dose-response curve using nonlinear regression (curve fit analysis) was used to detect all of these values. The values obtained from the means of triplicate experiments. ${ }^{c}$ Selective index calculated as the ratio of the $\mathrm{EC}_{50}$ of cell lines to the $\mathrm{IC}_{50}$ of each parasite. 


\subsection{Parasite Viability and Morphological Changes After Treatment With MEBV and AERC}

In the presence of $4 \times \mathrm{IC}_{50}(16.4$ and $3.24 \mu \mathrm{g} / \mathrm{mL}) \mathrm{MEBV}$, the regrowth of $B$. divergens and B. bigemina was completely suppressed, while T. equi, B. caballi, and B. bovis regrew even at $4 \times \mathrm{IC}_{50}$. AERC at $4 \times \mathrm{IC}_{50}(360,342.8$ and $312 \mu \mathrm{g} / \mathrm{mL})$ completely restricted T. equi, B. caballi and B. divergens regrowth, while $B$. bovis and B. bigemina were able to regrow even at $4 \times \mathrm{IC}_{50}$. Moreover, MEBV-and AERC-treated T. equi micrographs are shown in Figure 3. At $24 \mathrm{~h}$, all captured micrographs revealed spindle shapes dividing B. bigemina, B. bovis, and B. caballi parasites in contrast with the normal piriform shape of the untreated one, while dot-shaped residues of dead parasites were observed within the erythrocytes at $72 \mathrm{~h}$. At $24 \mathrm{~h}$, T. equi treated with MEBV and AERC were smaller and pyknotic when compared with the normal oval form of the untreated one. In subsequent micrographs taken at $72 \mathrm{~h}$, the dying parasites appeared dot-shaped (Figure 3).

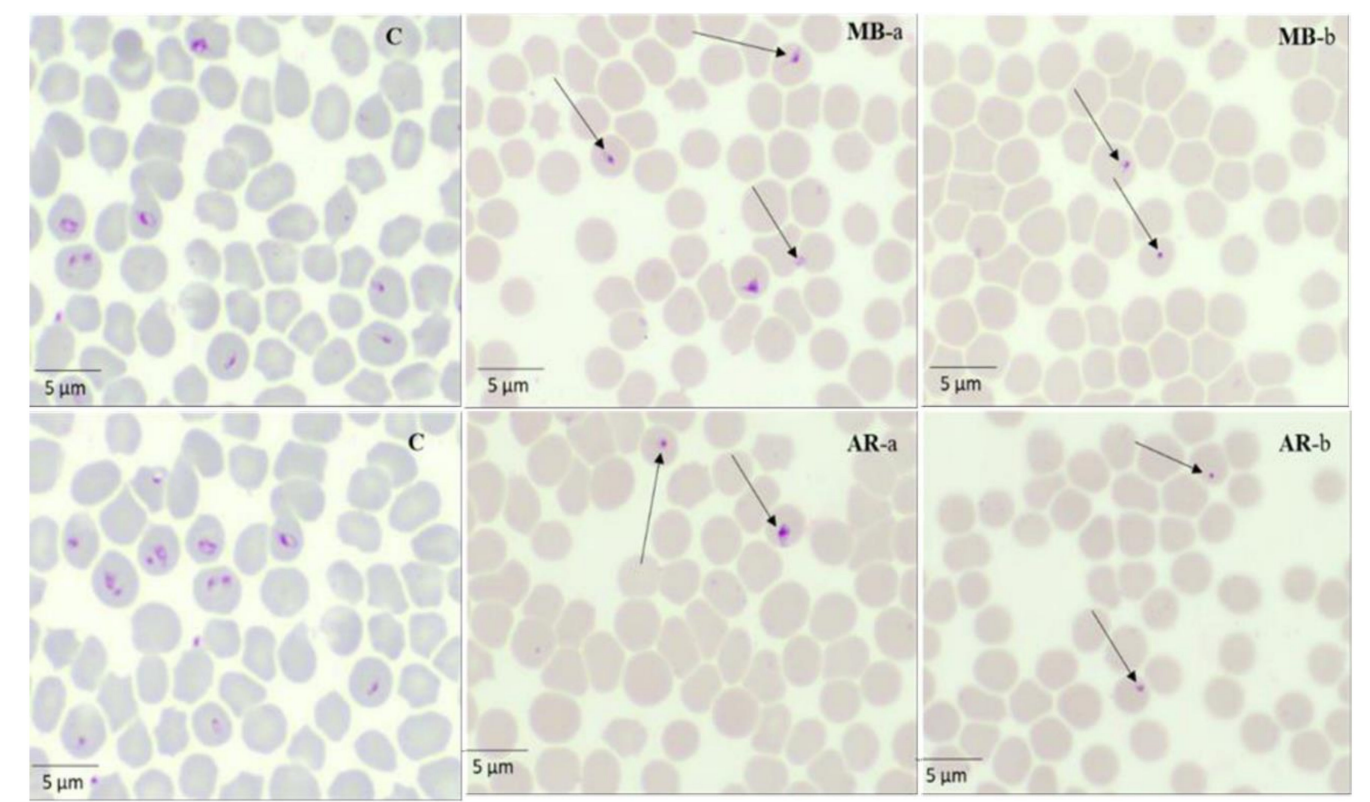

Figure 3. Morphological changes and light micrographs captured for MEBV- and AERC-treated T. equi in an in vitro culture taken after 24 (a) and $72 \mathrm{~h} \mathrm{(b).} \mathrm{The} \mathrm{arrows} \mathrm{show} \mathrm{the} \mathrm{abnormal} \mathrm{dividing} \mathrm{parasites}$ at $24 \mathrm{~h}$. While at $72 \mathrm{~h}$, drug-treated cultures showed higher numbers of degenerated parasites than did the control cultures.

\subsection{Toxicity of MEBV and AERC on Normal Cells}

The cytotoxicity assay of MEBV and AERC was estimated on HFF, NIH/3T3, and MDBK cell lines to detect their effect on the host cell viability. MEBV and AERC showed inhibition on MDBK and $\mathrm{NIH} / 3 \mathrm{~T} 3$ cell lines with $\mathrm{EC}_{50}$ shown in Table 3. Moreover, both extracts did not reduce the HFF cell viability at $1500 \mu \mathrm{g} / \mathrm{mL}$. For the reference antibabesial drugs, neither DMA nor ATV (final concentration $100 \mu \mathrm{M}$ ) restricted the viability of $\mathrm{HFF}, \mathrm{NIH} / 3 \mathrm{~T} 3$, or MDBK cell lines, while CLF in $\mathrm{EC}_{50}$ of $34 \pm 3.4 \mu \mathrm{M}$ reduced the MDBK cell viability (Table S2). The highest selective index values (ratio of the $\mathrm{EC}_{50}$ on the cell lines to the $\mathrm{IC}_{50}$ on the parasites) for MEBV and AERC were 1023.1 and 13.2 times toward T. equi and B. bigemina, respectively, whilst the lowest of MEBV and AERC was achieved on B. divergens with a selectivity index of 169.7 and on $B$. divergens with a selectivity index of 8.2, respectively (Table 3).

\subsection{In Vitro Potential of The Combination of MEBV and AERC With Other Drugs (ATV, DMA, and CLF)}

MEBV- and AERC-DMA treatment was additive toward all tested species except toward B. caballi it was synergetic. The combination treatments of MEBV and AERC with ATV or CLF were synergetic and additive toward all tested species (Table 4). 
Table 4. Combination effect of MEBV and AERC with DMA, ATV, and CLF in vitro.

\begin{tabular}{|c|c|c|c|c|c|c|c|}
\hline \multirow{2}{*}{ Parasites } & \multirow{2}{*}{ Drug Combinations $^{a}$} & \multicolumn{4}{|c|}{ CI Values $(\mu \mathrm{g} / \mathrm{mL})$} & \multirow{2}{*}{ Weighted Average CI Values ${ }^{b}$} & \multirow{2}{*}{ Degree of Association } \\
\hline & & $\mathrm{IC}_{95}$ & $\mathrm{IC}_{90}$ & $\mathrm{IC}_{75}$ & $\mathrm{IC}_{50}$ & & \\
\hline \multirow[t]{6}{*}{ B. bovis } & MEBV + DMA & 1.972 & 1.003 & 1.000 & 0.978 & 1.08900 & Additive \\
\hline & $\mathrm{AERC}+\mathrm{DMA}$ & 0.502 & 1.099 & 1.282 & 0.996 & 1.05300 & Additive \\
\hline & $\mathrm{MEBV}+\mathrm{ATV}$ & 0.722 & 1.691 & 0.968 & 0.908 & 1.06402 & Additive \\
\hline & $\mathrm{AERC}+\mathrm{ATV}$ & 0.865 & 1.297 & 0.913 & 0.973 & 1.00901 & Additive \\
\hline & $\mathrm{MEBV}+\mathrm{CLF}$ & 0.634 & 1.124 & 1.077 & 0.994 & 1.08900 & Additive \\
\hline & $\mathrm{AERC}+\mathrm{CLF}$ & 0.282 & 1.099 & 1.282 & 0.896 & 0.99099 & Additive \\
\hline \multirow[t]{6}{*}{ B. bigemina } & $\mathrm{MEBV}+\mathrm{DMA}$ & 2.460 & 1.004 & 1.004 & 0.768 & 1.05520 & Additive \\
\hline & $\mathrm{AERC}+\mathrm{DMA}$ & 1.7133 & 0.907 & 0.823 & 1.001 & 1.00003 & Additive \\
\hline & $\mathrm{MEBV}+\mathrm{ATV}$ & 0.9162 & 1.072 & 1.026 & 0.925 & 1.05402 & Additive \\
\hline & $\mathrm{AERC}+\mathrm{ATV}$ & 1.2597 & 0.827 & 0.889 & 0.85 & 0.89807 & Synergism \\
\hline & $\mathrm{MEBV}+\mathrm{CLF}$ & 0.578 & 0.872 & 0.926 & 0.725 & 0.80000 & Synergism \\
\hline & $\mathrm{AERC}+\mathrm{CLF}$ & 1.029 & 0.777 & 0.887 & 0.884 & 0.87801 & Synergism \\
\hline \multirow[t]{6}{*}{ B. divergens } & MEBV + DMA & 1.882 & 0.977 & 0.979 & 1.008 & 1.08050 & Additive \\
\hline & $\mathrm{AERC}+\mathrm{DMA}$ & 1.0326 & 0.878 & 1.038 & 1.132 & 1.04306 & Additive \\
\hline & $\mathrm{MEBV}$ + ATV & 1.946 & 0.897 & 0.987 & 1.002 & 1.07090 & Additive \\
\hline & $\mathrm{AERC}+\mathrm{ATV}$ & 0.8193 & 0.981 & 1.009 & 1.073 & 1.01003 & Additive \\
\hline & $\mathrm{MEBV}+\mathrm{CLF}$ & 1.3592 & 0.908 & 0.989 & 0.892 & 0.97102 & Additive \\
\hline & AERC + CLF & 1.5631 & 0.991 & 1.091 & 1.093 & 1.11901 & Additive \\
\hline \multirow{6}{*}{ B. caballi } & MEBV + DMA & 1.443 & 1.095 & 1.235 & 0.908 & 1.09701 & Additive \\
\hline & $\mathrm{AERC}+\mathrm{DMA}$ & 0.573 & 0.092 & 0.072 & 0.002 & 0.09809 & Synergism \\
\hline & MEBV + ATV & 1.302 & 1.082 & 1.102 & 1.009 & 1.08083 & Additive \\
\hline & AERC + ATV & 0.589 & 0.557 & 0.891 & 0.656 & 0.70003 & Synergism \\
\hline & MEBV + CLF & 0.557 & 0.787 & 0.787 & 0.577 & 0.68001 & Synergism \\
\hline & AERC + CLF & 0.230 & 0.281 & 0.201 & 0.153 & 0.20073 & Synergism \\
\hline \multirow[t]{6}{*}{ T. equi } & MEBV + DMA & 1.337 & 0.992 & 0.897 & 1.122 & 1.05003 & Additive \\
\hline & $\mathrm{AERC}+\mathrm{DMA}$ & 1.020 & 1.003 & 0.972 & 1.017 & 1.00104 & Additive \\
\hline & $\mathrm{MEBV}+\mathrm{ATV}$ & 1.330 & 0.839 & 0.998 & 1.142 & 1.05703 & Additive \\
\hline & $\mathrm{AERC}+\mathrm{ATV}$ & 0.086 & 0.191 & 0.098 & 0.059 & 0.09975 & Synergism \\
\hline & MEBV + CLF & 1.044 & 0.309 & 0.387 & 0.474 & 0.47190 & Synergism \\
\hline & $\mathrm{AERC}+\mathrm{CLF}$ & 0.4235 & 0.780 & 0.891 & 0.859 & 0.80925 & Synergism \\
\hline
\end{tabular}

a Two-drug combination between MEBV and AERC with DMA, CLF, and ATV at a concentration of approximately $0.25 \times, 0.5 \times$, IC $50,2 \times$, and $4 \times$ the IC $C_{50}$ (constant ratio). ${ }^{b}$ The weighted average $\mathrm{CI}$ value was calculated with the formula $\left[\left(1 \times \mathrm{IC}_{50}\right)+\left(2 \times \mathrm{IC}_{75}\right)+\left(3 \times \mathrm{IC}_{90}\right)+\left(4 \times \mathrm{IC}_{95}\right)\right] / 10{ }^{c}{ }^{\mathrm{c}}$ The degree of synergism was determined based on the following $\mathrm{CI}$ value: $<$ 0.90 (synergism), 0.90-1.10 (additive), and > 1.10 (antagonism). CI value, combination index value; $\mathrm{IC}_{50}, 50 \%$ inhibition concentration; DMA, diminazene aceturate; $\mathrm{ATV}$, atovaquone; CLF, clofazimine. 


\subsection{In Vivo Chemotherapeutic Efficacy of $M E B V$ and $A E R C$}

To examine the chemotherapeutic effects of MEBV and AERC in vivo, female BALB/c mice were affected by B. microti and the two drugs were administered for five days after the infection reach $1 \%$ parasitemia. On the eighth day post-infection (p.i.), the DDW control group showed rapid parasitemia growth reached $62.6 \%$ and the parasitemia reduced slowly on the subsequent days. The peak parasitemia level in all treated groups was $20.9 \%, 18.8 \%$ and $5 \%$ in MEBV (150 mg/kg BW), AERC (150 mg/kg BW) and DMA (25 mg/kg BW), respectively (Figure 4).

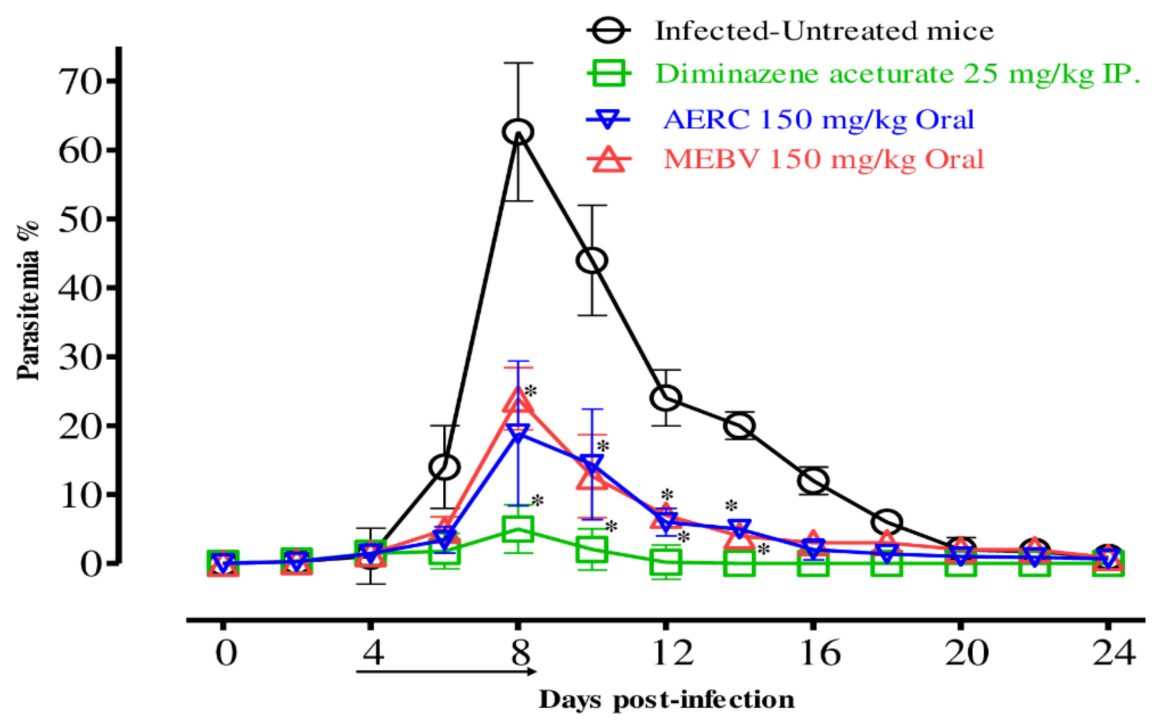

Figure 4. Growth inhibition effect of MEBV and AERC treatment against B. microti in vivo. The arrow indicates 5 consecutive days of treatment start from day 4 to 8 p.i. Asterisks indicate statistically significant $(p<0.05)$ differences of parasitemia between treated groups and the untreated group based on unpaired $t$-test analysis. Parasitemia was detected using Giemsa-stained thin blood smears by counting infected RBCs (iRBCs) among 2000 RBCs.

Moreover, the comparison of the hematology parameters during in vivo studies showed no significant difference in RBCs counts (Figure 5A), hematocrit (HCT) percentage (Figure 5B), hemoglobin (HGB) concentration (Figure 5C), or for the groups treated with MEBV as compared to the DMA-treated group on days 8 and 12 .
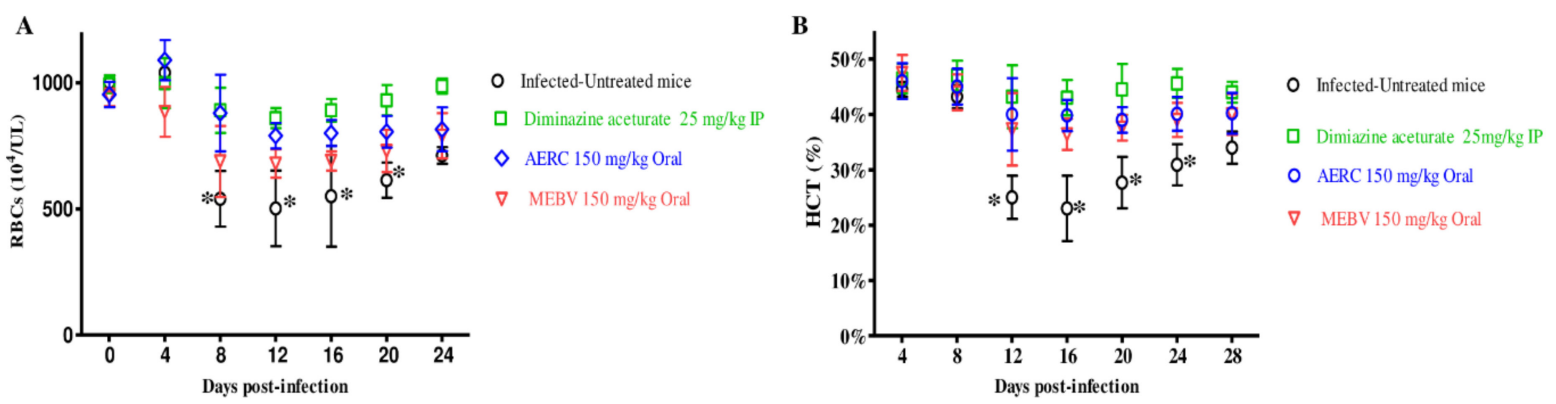

Figure 5. Cont. 
C

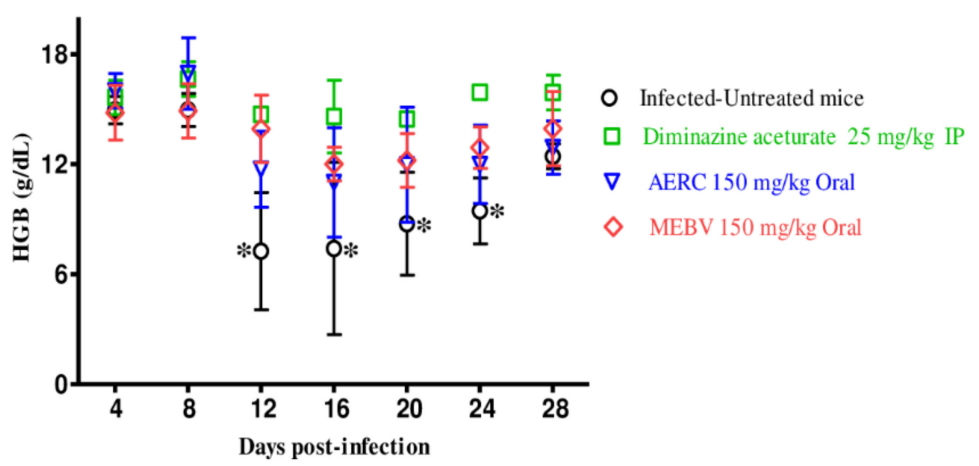

Figure 5. Hematology parameters changes in MEBV- and AERC-treated mice in vivo. Graphs showing the changes in RBCs count (A), HCT percentage (B), and HGB concentration (C) in mice treated with DMA and MEBV and AERC. Asterisks indicate statistical significance $(p<0.05)$ based on unpaired $t$-test analysis.

\section{Discussion}

In the current study, MEBV and AERC were examined for the existence of various biologically active compounds and the primary screening emphasized that both extracts containing terpenoids, alkaloids, flavonoids, and tannins. The qualitative examination revealed the presence of significant amounts of polyphenols and flavonoids. Notably, this finding conforms to the report by Gabr et al. [33] and Sequeda-Castañeda et al. [34] who revealed the existence of these active constituents in both extracts. It has been shown that all these secondary metabolites have many therapeutic properties and are known to be pharmacologically active components. Among these constituents, some flavonoids, polyphenols, and alkaloids have been reported to possess an antiparasitic effect against several parasites including, Plasmodium, Leishmania, Trypanosoma, Schistosoma and Trichomonas Vaginalis [35].

The phytochemical constituents of MEBV and AERC were detected using GC-MS analyses. The analysis revealed that MEBV consisted of 27 compounds, and the main chemical components identified were 3-(2-hydroxyphenyl) acrylic acid (15.55\%), $\alpha$-curcumene (13.27\%), 3-phenyl-2propen-1-ol, (10.16\%), phenyl ethyl alcohol (9.58\%), 2-methoxy-4-vinylphenol $(8.41 \%)$ and 4-hydroxy-4-methyl-2-pentanone (6.43\%). While AERC was found to possess 20 compounds and the main chemical components identified were 1,2,3-benzenetriol (pyrogallic acid) $(21.04 \%)$, 2-butenedioic acid (21\%), 1,4-p-menthadien-7-al (10.07\%), 4-(1-methylethyl) benzaldehyde (9.33\%), 4-hydroxy-4-methyl-2-pentanone (8.87\%) and methyl eugenol (3.60\%). Some of our GC-MS results were consistent with previous reports $[18,28-30]$, however, the difference in some compounds may be attributed to the type of solvents used and the extraction method.

For the in vitro experiments, MEBV revealed a growth-inhibiting effect against Babesia and Theileria parasites, whereas AERC exhibited high growth-inhibiting effects with high $\mathrm{IC}_{50}$ values against piroplasm parasites. Owing to the fact that Babesia, Theileria, and Plasmodium are classified into the same Apicomplexa phylum, the growth-inhibiting effect of MEBV and AERC against Babesia and Theileria parasites are consistent with those reported by Oryan. [16], and Rahimi-Madiseh et al. [18], who indicated that $B$. vulgaris extract was evaluated as a folk therapy for the treatment of fever and malaria. Additionally, Gathirwa et al. [29] showed that R. coriaria extract has antiplasmodial and antimalarial efficacy. In a separate report, the antimalarial action of $R$. coriaria was attributed to eriodictyol, 7-O-methylnaringenin, 7-O-methylluteolin, 30-O-dimethylquercetin, 7-O-methyl-apigenin, and di-O-methyl tetrahydroamentoflavone [30]. Further, diverse biological activities of MEBV have been attributed to the presence of berberine main active compounds [20]. Moreover, Fata et al. [25] investigated the effectiveness of alcoholic extracts of B. vulgaris against other parasites including cutaneous leishmaniasis. Interestingly, recent studies documented the antiprotozoal activities of various bioactive molecules identified in our GC-MS analysis. For instance, Le et al. [36] documented 
the antitrypanosomal activity of $\alpha$-curcumene, the main chemical component in MEBV with $\mathrm{IC}_{50}$ value of $13.38 \mu \mathrm{g} / \mathrm{mL}$ against Trypanosoma brucei brucei, whereas Andrade et al. [37] disclosed the antileishmanial efficacy of guaiol against Leishmania amazonensis promastigotes forms. Moreover, Colares et al. [38] and Le et al. [39] proved antileishmanial activity of eugenol and methyleugenol (the main chemical components in AERC) against promastigotes of L. amazonensis. In addition to that, $\beta$-guaiene and caryophyllene show antiprotozoal activity against P. falciparum, T. brucei, T. cruzi, L. amazonensis, and L. infantum with $\mathrm{IC}_{50}$ values ranging from 2.2 to $56.6 \mu \mathrm{g} / \mathrm{mL}$ [40]. Sena-Lopes et al. [41] investigated the antiprotozoal effect of methyleugenol, $\beta$-caryophyllene and $\alpha$-curcumene against the growth of T. vaginalis, with an $\mathrm{IC}_{50}$ value of $100 \mu \mathrm{g} / \mathrm{mL}$. The GC-MS analysis of Syzygium (S.) aromaticum documented the presence of eugenol, $\beta$-guaiene, caryophyllene, and $\alpha$-ylangene which showed potent antipiroplasmic effect in vitro and in vivo [9,42]. Therefore, we hypothesized that $\alpha$-curcumene, guaiol, $\alpha$-guaiene, $\alpha$-ylangene, caryophyllene, and methyleugenol are the main active compounds responsible for the antipiroplasmic activity of MEBV and AERC.

It is likely that more than one bioactive ingredient restricts piroplasm parasites multiplication, thus, elucidating the inhibitory effectiveness of MEBV and AERC would require further studies. As compared to previous studies, MEBV IC 50 values against Babesia parasites were less than those of S. aromaticum methanolic extract toward bovine Babesia (B. bovis and B. bigemina) [9]. While, AERC $\mathrm{IC}_{50}$ values toward Babesia parasites were less than those of Uncaria tomentosa acetonic extract, Myrtus communis acetonic extract, Origanum vulgare ethanolic extract, and Cuminum cyminum methanolic extract toward bovine Babesia (B. bovis and B. bigemina) [6]. A viability study revealed that MEBV and AERC have the ability to restrict piroplasm parasites regrowth. For instance, $B$. caballi and $B$. divergens treated with MEBV did not revive at $4 \times \mathrm{IC}_{50}$ concentration. While, AERC suppressed B. caballi, T. equi and $B$. divergens regrowth at $4 \times \mathrm{IC}_{50}$. However, there is a need for additional researches to isolate and identify the effective compounds from MEBV and AERC and evaluate the actual mode of action employed against the recovery of piroplasm parasites.

Additionally, MEBV and AERC treatment resulted in morphological changes in the treated parasites observed in micrographs taken at different incubation times. The captured micrographs revealed that Babesia and Theileria parasites were not able to eject and thus, died inside the iRBCs. Interestingly, recent studies revealed that the organic extract of $B$. vulgaris and $R$. coriaria extracts showed a significant antiparasitic effect toward P. falciparum and Leishmania with multiple morphological changes of the parasites $\left[16,29,31\right.$ ]. Oryan. [16] showed that the $\mathrm{IC}_{50}$ of $B$. vulgaris was $45.5 \mu \mathrm{g} / \mathrm{mL}$ with the highest inhibitory effect on promastigotes multiplication and morphological changes, demonstrating that, the extracts prepared from $B$. vulgaris showed more promising antileishmanial activity against both stages of the parasite. Gathirwa et al. [31] showed that the high activity of $R$. natalensis and chemosuppression $83.15 \%$ for $R$. coriaria against $P$. falciparum, explained the Rhus plant's potential.

The attempts to determine the cytotoxic effect of our extracts revealed that MEBV and AERC inhibited HFF, NIH/3T3, and MDBK cell viability at a slightly high selectivity index. Thus, suggesting that the tested extracts are able to act on Babesia and Theileria without affecting the host cells. These results are comparable with that of Oryan. [16], who reported the lower cytotoxicity of B. vulgaris against host cells $\left(\mathrm{IC}_{50}=390.5 \mu \mathrm{g} / \mathrm{mL}\right)$, with an excellent selectivity index equal to 24. Gathirwa et al. [31] showed that $R$. coriaria did not show any cytotoxic effect on mammalian cells with an $\mathrm{EC}_{50}$ of $211.78 \mu \mathrm{g} / \mathrm{mL}$ and a selective index value of 2.78 .

Nowadays, combination chemotherapies are used to treat serious ailments, including pulmonary tuberculosis, malignancy, immune deficiency syndrome, and some protozoal diseases to promote higher therapeutic efficacy [43]. The recent strategy to enhance the therapeutic effect in Chinese medicine which began a long time ago relies on the use of herb-herb and herb-compound combination [10]. MEBV and AERC combined with DMA exhibited an additive efficacy toward all species tested. The combined application of MEBV and AERC with ATV and CLF showed an additive and synergetic relationship toward T. equi, B. divergens, B. bigemina, B. caballi, and B. bovis. One possible explanation is that herbal extracts contain many bioactive ingredients that may interact differently resulting in 
synergistic action observed for combination treatment. The implication of this is that the plant extracts could be used as an adjuvant to the piroplasmosis therapy.

MEBV and AERC produced promising in vivo antibabesial activity. On the eighth-day post-infection, oral administration of $150 \mathrm{mg} / \mathrm{kg}$ of MEBV and AERC resulted in $66.7 \%$ and $70 \%$ inhibition compared to $92 \%$ inhibition showed by DMA at $25 \mathrm{mg} / \mathrm{kg}$. MEBV exhibited chemotherapeutic efficacy higher than the $42.4 \%$ demonstrated by Camellia sinensis methanolic extract [9], while the inhibitory effect of AERC was higher than the $69.2 \%$ demonstrated by S. aromaticum methanolic extract [9]. Furthermore, neither the MEBV nor the AERC treatment showed any apparent toxic symptoms or promoted anemia in uninfected mice. The chemotherapeutical effectiveness induced by MEBV and AERC toward B. microti implicates that they may be alternate chemotherapy against B. microti infection in humans. Therefore, identifying the active compound is necessary for contriving a higher chemosuppression effect from these extracts for the future discovery of a novel potential drug against piroplasmosis.

The limitation of this study is the use of the whole extract to confirm the antiprotozoal activity, and it is recommended to evaluate the antipiroplasmic efficacy of the GC-MS identified compounds for the future discovery of a novel potential drug against piroplasmosis. And evaluate the actual mode of action employed against the recovery of piroplasm parasites.

\section{Conclusions}

MEBV and AERC demonstrated the in vitro and in vivo chemotherapeutic potentials against the multiplication of several piroplasm parasites both in vitro and in vivo, implying that both extracts have potential value in treating clinical diseases in animals and humans either alone or in combination with other drugs. The GC-MS analysis documented the presence of many phytochemical compounds that may be responsible for the babesicidal activities of MEBV and AERC.

\section{Materials and Methods}

\subsection{Ethical Statement}

The in vivo studies were conducted based on the local guidelines for animal experimentation, as approved by the Obihiro University of Agriculture and Veterinary Medicine, Japan (accession numbers 28-111-2, 28-110, and 1417-2). This ethical approval was developed through the basic guidelines for the proper conduct of animal experimentation and related activities in Academic Research Institutions, Ministry of Education, Culture, Sports and Technology (MEXT), Japan.

\subsection{Chemical Reagents}

Stock solutions (100 mg (crude extract)/ $1 \mathrm{~mL}$ (DMSO) and $10 \mathrm{mM}$ ) in dimethyl sulfoxide (DMSO) of crude extract and DMA (Ciba-Geigy Japan limited, Tokyo, Japan), ATV and CLF (Sigma-Aldrich, Tokyo, Japan), respectively were stored at $-30^{\circ} \mathrm{C}$ and used for antibabesiosis evaluation. Reference drugs including DMA, CLF, and ATV were used either singly and/or in combination with the two extracts for both the in vivo and in vitro experiments. For the fluorescence assay, SYBR Green I (SGI) stain $(10,000 \times$, Lonza, Alpharetta, GA, USA) was mixed with the lysis buffer containing saponin $(0.016 \% w / v)$, EDTA $(10 \mathrm{mM})$, Triton $\mathrm{X}-100(1.6 \% v / v)$, and Tris $(130 \mathrm{mM}$ at $\mathrm{pH} 7.5)$ which was filtered using a polyethersulfone $(0.22 \mu \mathrm{m})$ and kept at $4{ }^{\circ} \mathrm{C}$.

\subsection{Herbal Plants}

Berberis vulgaris and R. coriaria were collected from Delta, Egypt and identified by the members of the Pharmacology and Chemotherapeutics Department, Faculty of Veterinary Medicine, Damanhour University, Egypt. B. vulgaris and R. coriaria voucher specimen numbers are A0177105 (DPV) and A 0177106 (DPV), respectively. An electric dryer (Sanyo Electric Co., Ltd., Osaka, Japan) was used to dry the plants at a temperature of $30^{\circ} \mathrm{C}$, then ground using a $60-80 \mathrm{~mm}$ mesh to a fine powder. 
Subsequently, fine plant powder (100 g) was dissolved in methanol (99.8\%) (Wako Pure chemical Industrial, Ltd, Osaka, Japan) or acetone (99.5\%) (Nacalai Tesque, Kyoto, Japan) (50 mL) and incubated for $72 \mathrm{~h}$ at a temperature of $30^{\circ} \mathrm{C}$. The preparation of slurry extract was performed following the method as previously described $[9,18,44]$ and the extracted stock $(100 \mathrm{mg} / 1 \mathrm{~mL}$ DMSO) was stored at $-30^{\circ} \mathrm{C}$ and used for antibabesiosis evaluation. The obtained extracts of the MEBV and AERC were 7.31 and $8.06 \mathrm{~g}$, respectively, and the yield percentage was calculated using the following Equation [45]:

$$
\text { Percentage yield of extract }=\frac{\text { Weight of extracted material }}{\text { Weight of original plant material used }} \times 100
$$

\subsection{Phytochemical Examination of Plant Extracts}

MEBV and AERC were examined for the existence of terpenoids, saponins, tannins, and alkaloids using several qualitative tests as previously reported elsewhere [46].

\subsection{Determination of Total Phenolic Content}

The concentration of total phenolic content (polyphenols) present in MEBV and AERC was detected using Folin-Ciocalteu (FC) reagent method as described elsewhere [47]. A volume of $0.5 \mathrm{~mL}$ of both extracts $(1 \mathrm{mg} / \mathrm{mL}$ ) was added to $1.5 \mathrm{~mL}$ of $10 \%$ FC reagent (diluted 1:10 with de-ionized water) and mixed for $5 \mathrm{~min}$. After that, an aliquot $(3 \mathrm{~mL})$ of $7.5 \% \mathrm{Na}_{2} \mathrm{CO}_{3}$ solution was added and further incubated at $30^{\circ} \mathrm{C}$ for $2 \mathrm{~h}$. Finally, the absorbance was calculated at $760 \mathrm{~nm}$ and the content of total phenolic compounds was detected from a gallic acid standard curve and expressed as $\mathrm{mg} / \mathrm{g}$ gallic acid equivalent (GAE) of the dry weight of the extract (mg GAE/g DW).

\subsection{Determination of Total Flavonoid Content}

Aluminium chloride $\left(\mathrm{AlCl}_{3}\right)$ colorimetric method was used for the examination of total flavonoid content in MEBV and AERC as previously determined [47]. Briefly, an aliquot $(1 \mathrm{~mL})$ of both extracts was added to $3 \mathrm{~mL}$ of solvent extracts, $3.8 \mathrm{~mL}$ of distilled water, $200 \mu \mathrm{L}$ of $1 \mathrm{M}$ potassium acetate and $200 \mu \mathrm{L}$ of $10 \% \mathrm{AlCl}_{3}$ and incubated for $30 \mathrm{~min}$. The absorbance was measured at $420 \mathrm{~nm}$ and the flavonoid content was detected from a catechin standard curve and expressed as $\mathrm{mg} / \mathrm{g}$ catechin equivalents of the dry weight of individual extract (mg CAE/g DW).

\subsection{Gas Chromatography-Mass Spectrometry (GC-MS) Analysis}

The chemical composition of MEBV and AERC was performed using Trace GC-ISQ mass spectrometer (Thermo Scientific, Austin, TX, USA) with a direct capillary column TG-5MS ( $30 \mathrm{~m} \times 0.25 \mathrm{~mm} \times 0.25 \mu \mathrm{m}$ film thickness) as previously described [48]. The column oven temperature was initially held at $50{ }^{\circ} \mathrm{C}$ and then increased by $5{ }^{\circ} \mathrm{C} / \mathrm{min}$ to $250{ }^{\circ} \mathrm{C}$ withhold $1 \mathrm{~min}$ then increased to 300 at rate of $30^{\circ} \mathrm{C} / \mathrm{min}$. The injector temperatures were kept at $260{ }^{\circ} \mathrm{C}$. Helium was used as a carrier gas at a constant flow rate of $1 \mathrm{~mL} / \mathrm{min}$. The solvent delay was $4 \mathrm{~min}$ and diluted samples of $1 \mu \mathrm{L}$ were injected automatically using an AS3000 Autosampler coupled with GC in the split mode. EI mass spectra were collected at $70 \mathrm{eV}$ ionization voltages over the range of $m / z 50-650$ in full scan mode. The ion source and transfer line were set at $250^{\circ} \mathrm{C}$ and $270{ }^{\circ} \mathrm{C}$, respectively. The components were identified by comparison of their retention times and mass spectra with those of WILEY 09 and NIST 11 mass spectral databases.

\subsection{Parasites and Mice}

For conducting in vitro experiments, B. bigemina Argentine strain [49], B. divergens Germany strain, Texas strain B. bovis were cultured in cattleRBCs, whereas United States Department of Agriculture (USDA) strains B. caballi and T. equi were maintained in horse RBCs; for conducting in vivo study, eight-week-old female BALB/c mice weighing 25 grams (g) were obtained from CLEA Japan and infected with rodent-borne parasitic nonzoonotic agent, B. microti Munich strain (AB071177) [49-51]. 
All parasites were incubated and maintained at $37^{\circ} \mathrm{C}$ in a humidified chamber under $90 \% \mathrm{~N}_{2}, 5 \% \mathrm{O}_{2}$ and $5 \% \mathrm{CO}_{2}$ atmosphere using a microaerophilic stationary-phase culture [5].

\subsection{Culture Conditions}

GIT medium replenished with $40 \%$ horse serum was used as a growth medium for B. caballi parasite culture, while T. equi was grown in medium 199 (M199) supplemented with hypoxanthine (MP Biomedicals, Santa Ana, CA, USA; final concentration $13.6 \mu \mathrm{g} / \mathrm{mL}$ ). Babesia divergens was preserved in Roswell Park Memorial Institute 1640 (RPMI 1640; Sigma-Aldrich, Tokyo, Japan) medium, replenished with $40 \%$ cattle serum and culture medium M199 was used as a growth medium for B. bovis and B. bigemina replenished with $40 \%$ cattle serum. To ensure free-bacterial contamination, all medium was supplemented with amphotericin B $(0.15 \mu \mathrm{g} / \mathrm{mL})$ (Sigma-Aldrich, St. Louis, MO, USA), streptomycin $(60 \mathrm{U} / \mathrm{mL})$ and penicillin $\mathrm{G}(60 \mathrm{U} / \mathrm{mL})$.

\subsection{The Inhibition Assay of MEBV and AERC In Vitro}

The Babesia fluorescent assay was carried out on the in vitro culture as previously reported elsewhere $[5,52,53]$. RBCs' stock supply at $1 \%$ parasitemia was prepared by diluting parasite-iRBCs with uninfected RBCs. Briefly, in three separate trials, using two-fold dilution, different concentrations of MEBV, AERC, ATV, CLF, and DMA were prepared in the culture medium and added in 96-well plates in triplicate with $1 \%$ parasitemia and $2.5 \%$ HCT for B. bigemina and B. bovis and $5 \%$ HCT for T. equi, B. caballi and B. divergens. The positive control had iRBCs with final concentration of $0.3 \%$ of DMSO, whereas uninfected RBCs and the culture medium acted as the negative control. Afterward, parasite cultures were cultivated for 4 consecutive days without changing medium at $37^{\circ} \mathrm{C}$ humidified multi-gas incubator in $90 \% \mathrm{~N}_{2}, 5 \% \mathrm{O}_{2}$, and $5 \% \mathrm{CO}_{2}$ atmosphere. On day four of culture, an aliquot of lysis buffer $(100 \mu \mathrm{L})$ was mixed with $0.2 \mu \mathrm{L} / \mathrm{mL}$ SG1 and gently added per well; subsequently, it was covered with aluminum foil to prevent exposure to light. After a 6-h incubation at $37^{\circ} \mathrm{C}$, fluorescence readings were acquired on a spectrofluorimeter (Fluoroskan Ascent, Thermo Fisher Scientific, Oceanside, CA, USA) with an excitation wavelength of $485 \mathrm{~nm}$ and an emission wavelength of $518 \mathrm{~nm}$.

\subsection{Parasite Viability Test In Vitro and Morphological Changes}

The viability studies were monitored via microscopy as described previously $[4,9,52]$. Briefly, an aliquot $(20 \mu \mathrm{L})$ of infected RBCs ( $1 \%$ parasitemia) was cultivated in $200 \mu \mathrm{L}$ of media containing various concentrations of MEBV and AERC for 4 successive days, changing media daily. The concentrations used in this experiment were $0.25 \times, 0.5 \times, 1 \times, 2 \times$, and $4 \times$ the $\mathrm{IC}_{50}$. On the fifth day, a mixture of iRBCs $(6 \mu \mathrm{L})$ from each well and fresh equine or bovine RBCs $(14 \mu \mathrm{L})$ was transferred to another plate, cultured in a medium free from drug and then left for an additional six days. The total parasite clearance was recorded as negative, while the relapse of parasites was recorded as positive.

\subsection{Evaluation of The Impacts of $M E B V$ and AERC on RBCs of Host}

The hemolytic efficacy of MEBV and AERC on cattle and horse RBCs was evaluated in vitro as previously reported elsewhere [51]. Initially, MEBV and AERC at a concentration of $300 \mu \mathrm{g} / \mathrm{mL}$ were cultivated at $37^{\circ} \mathrm{C}$ with purified bovine and equine RBCs for $3 \mathrm{~h}$. Afterward, the pretreated-RBCs were added to T. equi- and B. bovis-iRBCs after washing thrice with phosphate-buffered saline (PBS) to achieve $1 \%$ parasitemia. Thereafter, using a 24 -well plate, an aliquot of iRBCs $(100 \mu \mathrm{L})$ was mixed with culture media $(900 \mu \mathrm{L})$; the control RBCs were left untreated. To monitor the parasitemia and any side effects due to the pretreatment, Giemsa-stained smears were prepared every $24 \mathrm{~h}$ for four days. 


\subsection{In Vitro Efficacy of The Drug Combination Treatment}

The combined efficacy of MEBV and AERC with DMA or CLF or ATV was examined using the fluorescence inhibition assay as reported previously elsewhere [4,9,52,53]. Briefly, two-drug combinations of MEBV and AERC with DMA or CLF or ATV at five selected concentrations $0.25 \times, 0.5 \times$, $1 \times, 2 \times$, and $4 \times$ the $\mathrm{IC}_{50}$ (Table S1) were added in 96 well-plates in duplicate. The drug cultivation and the fluorescence values were detected after the addition of $2 \times$ SGI mixed with lysis buffer to each well of the 96-well plate as described above. CompuSyn software was used for combination index (CI) values calculation and the synergetic degree was established as the average weighted $\mathrm{CI}$ values by using the following formulae; $\left.\left(\left(1 \times \mathrm{IC}_{50}\right)+\left(2 \times \mathrm{IC}_{75}\right)+\left(3 \times \mathrm{IC}_{90}\right)+\left(4 \times \mathrm{IC}_{95}\right)\right) / 10\right)$ and the resulted values were demonstrated using the recommended CI scale; lower than 0.90 was considered synergetic, between 0.90-1.10 was considered additive, while higher than 1.10 was considered antagonistic developed previously $[53,54]$.

\subsection{Cultures of Normal Cell Lines}

Cultures of Human foreskin fibroblast (HFF; HFF-1 ATCC@SCRC-1041 ${ }^{\mathrm{TM}}$ ), Madin-Darby bovine kidney (MDBK; ECACC) and mouse embryonic fibroblast (NIH/3T3; ATCC@CRL-1658 ${ }^{\mathrm{TM}}$ ) cell lines were retrieved from $-80{ }^{\circ} \mathrm{C}$ stock and cultured continuously at $37^{\circ} \mathrm{C}$ under atmosphere $5 \% \mathrm{CO}_{2}$ in our laboratory. The NIH/3T3 and HFF cell lines were maintained in Dulbecco Modified Eagle's Medium (DMEM; Gibco, Grand Island, NY, USA), while MDBK cell line grown in Minimum Essential Medium Eagle (MEM; Gibco). Each medium was treated with 1\% glutamine, 10\% fetal bovine serum and $0.5 \%$ penicillin/streptomycin (Gibco). Every 72 to $96 \mathrm{~h}$, the medium was replaced, and once $80 \%$ confluence was reached, the cell collection was performed by sub-culture protocol. To confirm the absence of mycoplasma contamination, 4,6-diamidino-2-phenylindole dihydrochloride (Sigma-Aldrich) stain was used [9].

\subsection{Cytotoxicity Assay of MEBV and AERC on Normal Cells}

The cell viability test was conducted in a 96-well plate as described elsewhere $[4,9,51,52]$. Briefly, an aliquot of $(100 \mu \mathrm{L})$ cells was implanted at a concentration of $5 \times 10^{4}$ cells/mL in DMEM or MEM with fetal bovine serum and incubated overnight under atmosphere $5 \% \mathrm{CO}_{2}$ at $37{ }^{\circ} \mathrm{C}$ for attachment. Using two-fold dilutions, aliquots $(10 \mu \mathrm{L})$ were added in triplicate to each well to attain final concentrations of 15.8 to $1500 \mu \mathrm{g} / \mathrm{mL}$ and incubated for an additional $24 \mathrm{~h}$. The positive control wells containing cells mixed with the medium in $0.4 \%$ DMSO, whereas the negative control wells containing culture medium only. After a 24-h incubation, Cell Counting Kits-8 (CCK-8) (10 $\mu \mathrm{L})$ was added per well followed by the incubation of the plate for another 3 hours and a microplate reader was used to measure the absorbance at $450 \mathrm{~nm}$.

\subsection{In Vivo Chemotherapeutic Effects of $M E B V$ and AERC}

MEBV and AERC were examined for their in vivo chemotherapeutic efficacy using B. microti-infected BALB/C mice according to a procedure described elsewhere $[49,51]$. Briefly, twenty-five mice were placed in an environment free from pathogens with $22{ }^{\circ} \mathrm{C}$ temperature and adjusted humidity and under $12 \mathrm{~h}$ light and $12 \mathrm{~h}$ darkness and randomly distributed into five groups. All mice in groups 2 through 5 obtained $500 \mu \mathrm{L}$ of $1 \times 10^{7}$ B. microti-iRBC by intraperitoneal (i.p.) injection. Group 1 served as a negative control and was neither infected nor treated. At $1 \%$ parasitemia, drug treatment of the mice by i.p. continuing for five days. Group 2 act as a positive control group and received 95\% double-distilled water (DDW) and 5\% DMSO. Groups 3 and 4 administered $150 \mathrm{mg} / \mathrm{kg}$ body weight (BW) of MEBV and AERC by the oral route, respectively. While group 5 received $25 \mathrm{mg} / \mathrm{kg}$ BW of DMA to act as a reference to drug control. The drug administration lasted for five days starting from the fourth day to the eighth day post-infection (p.i.), and parasitemia was monitored by preparing Giemsa-stained blood smears every two days in about 5000 RBCs by 
microscopy until day 32 p.i. Furthermore, the hematological parameters, including HGB, RBCs, and HCT percentage were examined every four days using an automatic hematology analyzer (Celltac $\alpha$ MEK-6450, Nihon Kohden, Tokyo, Japan) to detect the effect of MEBV and AERC on the retrogression of anemia related to Babesia infection. At the end of the in vivo experiment, an anesthetic system using an inhaler containing isoflurane was used to euthanize all mice by placing them in the induction chamber, adjusting the oxygen flowmeter to 0.8 to $1.5 \mathrm{~L} / \mathrm{min}$ and vaporizer to $3 \%$ to $5 \%$. When mice were completely anesthetized, all of them were killed by cervical dislocation according to the ethical approval confirmed by the Basic Guidelines for Proper Conduct of Animal Experiment and Related Activities in Academic Research Institutions, the Ministry of Education, Culture, Sports and Technology (MEXT), Japan.

\subsection{Statistical Analysis}

The nonlinear regression curve fit on a GraphPad Prism (GraphPad Software Inc., USA) was used to determine the $\mathrm{IC}_{50}$ values of MEBV, AERC, DMA, CLF, and ATV from in vitro growth of the parasites. The significant variations $(p<0.05)$ among group mean values on parasitemia and Student's $t$-test, available in the GraphPad Prism software was used to analyze hematology profiles in mice infected with B. microti.

Supplementary Materials: The following are available online. Table S1. The concentrations of the in vitro combination treatment of methanolic B. vulgaris and acetonic $R$. coriaria extracts with ATV, DMA, and CLF toward piroplasm parasites. Table S2. The $\mathrm{IC}_{50}$ and selective indexes value of DMA, CLF, and ATV. Figure S1. Gas chromatography-mass spectrometry analysis in the methanolic extract of Berberis vulgaris. Figure S2. Gas chromatography-mass spectrometry analysis in the acetonic extract of Rhus coriaria.

Author Contributions: Conceptualization and methodology, G.E.-S.B. and A.M.B.; statistical analysis and the results analysis, O.S.A., E.H.N., E.k.M.R., L.M.A., A.A.E.; critical advice and supervision, L.M.A., N.Y. and I.I.; writing-original draft preparation, G.E.S, and A.M.B.; writing subsequent drafts, O.A.D., E.N., E.R., L.M.A., A.A.E., N.Y. and I.I.; writing-review and editing, G.E.S., A.M.B., and I.I. All authors have read and agreed to the published version of the manuscript.

Funding: This study was supported by the Ministry of Higher Education Egypt, the Japanese Society for the Promotion of Science, and the Ministry of Education, Culture, Sports, Science and Technology, Japan (JSPS) (KAKEN Grant Number: 18H02337).

Acknowledgments: The authors would like to thank members of the Pharmacology and Chemotherapeutics Department, Faculty of Veterinary Medicine, Damanhour University, Egypt for collecting and identification of plants and Sambuu Gantuya for her technical assistance.

Conflicts of Interest: The authors declare that they have no competing interests.

\section{References}

1. Hasheminasab, S.S.; Moradi, P.; Wright, I. A four year epidemiological and chemotherapy survey of babesiosis and theileriosis, and tick vectors in sheep, cattle and goats in Dehgolan, Iran. Ann. Parasitol. 2018, 64, 43-48.

2. Vannier, E.G.; Diuk-Wasser, M.A.; Ben Mamoun, C.; Krause, P.J. Babesiosis. Infect. Dis. Clin. North Am. 2015, 29, 357-370. [CrossRef] [PubMed]

3. Mosqueda, J.; Olvera-Ramirez, A.; Aguilar-Tipacamu, G.; Canto, G.J. Current advances in detection and treatment of babesiosis. Curr. Med. Chem. 2012, 19, 1504-1518. [CrossRef] [PubMed]

4. Batiha, G.E.S.; Beshbishy, A.M.; Tayebwa, D.S.; Adeyemi, O.S.; Shaheen, H.; Yokoyama, N.; Igarashi, I. The effects of trans-chalcone and chalcone 4 hydrate on the growth of Babesia and Theileria. PLoS Negl. Trop. Dis. 2019, 13, e0007030. [CrossRef] [PubMed]

5. Guswanto, A.; Nugraha, A.B.; Tuvshintulga, B.; Tayebwa, D.S.; Rizk, M.A.; Batiha, G.E.-S.; Gantuya, S.; Sivakumar, T.; Yokoyama, N.; Igarashi, I. 17-DMAG inhibits the multiplication of several Babesia species and Theileria equi on in vitro cultures, and Babesia microti in mice. Int. J. Parasitol. Drugs Drug Resist. 2018, 8, 104-111. [CrossRef] [PubMed]

6. Batiha, G.E.S.; Beshbishy, A.M.; Tayebwa, D.S.; Shaheen, M.H.; Yokoyama, N.; Igarashi, I. Inhibitory effects of Uncaria tomentosa bark, Myrtus communis roots, Origanum vulgare leaves and Cuminum cyminum seeds extracts against the growth of Babesia and Theileria in vitro. Jap. J. Vet. Parasitol. 2018, 17, 1-13. 
7. Batiha, G.E.; El-Far, A.H.; El-Mleeh, A.A.; Alsenosy, A.A.; Abdelsamei, E.K.; Abdel-Daim, M.M.; El-Sayed, Y.S.; Shaheen, H.M. In vitro study of ivermectin efficiency against the cattle tick, Rhipicephalus (Boophilus) annulatus, among cattle herds in El-Beheira, Egypt. Vet. World 2019, 12, 1319-1326. [CrossRef]

8. Iyiola, O.A.; Sulaiman, A.F.; Sulaiman, A.A.; Anifowoshe, A.T.; Akolade, J.O.; Adisa, M.J.; Otohinoyi, D.A.; Rotimi, D.E.; Batiha, G.E.S.; Maimako, R.F.; et al. Cypermethrin and chlorpyrifos raises serum urea level and causes abnormal sperm morphology in Wistar rats. Biointer. Res. Appl. Chem. 2019, 9, 3969-3973.

9. Batiha, G.E.S.; Beshbishy, A.M.; Tayebwa, D.S.; Shaheen, M.H.; Yokoyama, N.; Igarashi, I. Inhibitory effects of Syzygium aromaticum and Camellia sinensis methanolic extracts on the growth of Babesia and Theileria parasites. Ticks Tick. Borne Dis. 2019, 10,949-958. [CrossRef]

10. Sulaiman, F.A.; Nafiu, M.O.; Yusuf, B.O.; Muritala, H.F.; Adeyemi, S.B.; Omar, S.A.; Dosumu, K.A.; Adeoti, Z.J.; Adegbesan, O.A.; Busari, B.O.; et al. The GC-MS fingerprints of Nicotiana tabacum L. extract and propensity for renal impairment and modulation of serum triglycerides in Wistar rats. J. Pharm. Pharmacogn. Res. 2020, 8, 191-200.

11. Adeyemi, O.S.; Atolani, O.; Awakan, O.J.; Olaolu, T.D.; Nwonuma, C.O.; Alejolowo, O.; Otohinoyi, D.A.; Rotimi, D.; Owolabi, A.; Batiha, G.E. Focus: Organelles: In vitro screening to identify anti-Toxoplasma compounds and in silico modeling for bioactivities and toxicity. Yale J. Biol. Med. 2019, 92, 369.

12. Che, C.T.; Wang, Z.J.; Chow, M.S.S.; Lam, C.W.K. Herb-herb combination for therapeutic enhancement and advancement: Theory, practice and future perspectives. Molecules 2013, 18, 5125-5141. [CrossRef]

13. Sheng, W.D.; Jiddawi, M.S.; Hong, X.Q.; Abdulla, S.M. Treatment of chloroquine-resistant malaria using pyrimethamine in combination with berberine, tetracycline or cotrimoxazole. East Afr. Med. J. 1997, 74, 283-284.

14. Rocha, L.G.; Almeida, J.R.; Macedo, R.O.; Barbosa Filho, J.M. A review of natural products with antileishmanial activity. Phytomedicine 2005, 12, 514-535. [CrossRef] [PubMed]

15. Ghaderi, R.; Maleki Nejad, P. Evaluation of anti-candidal effects of Berberis vulgaris root extracts (methanolic and aqueous) and comparing their effects with those clotrimazole. J. Birjand Univ. Med. Sci. 2006, 13, 42-48.

16. Oryan, A. Plant-derived compounds in the treatment of leishmaniasis. Iran. J. Vet. Res. 2015, 16, 1-19.

17. Tomosaka, H.; Chin, Y.W.; Salim, A.A.; Keller, W.J.; Chai, H.; Kinghorn, A.D. Antioxidant and cytoprotective compounds from Berberis vulgaris (Barberry). Phytother. Res. 2008, 22, 979-981. [CrossRef]

18. Rahimi-Madiseh, M.; Lorigoini, Z.; Zamani-Gharaghoshi, H.; Rafieian-Kopaei, M. Iranian Journal of Basic Medical Sciences Berberis vulgaris: Specifications and traditional uses. Iran. J. Basic Med. Sci. 2017, 20, 569-587.

19. Mokhber-Dezfuli, N.; Saeidnia, S.; Gohari, A.R.; Kurepaz-Mahmoodabadi, M. Phytochemistry and pharmacology of berberis species. Pharmacogn. Rev. 2014, 8, 8-15.

20. Mahmoudvand, H.; Sharififar, F.; Sharifi, I.; Ezatpour, B.; Fasihi Harandi, M.; Makki, M.S.; Zia-Ali, N.; Jahanbakhsh, S. In vitro inhibitory effect of Berberis vulgaris (Berberidaceae) and its main component, berberine against different Leishmania species. Iran. J. Parasitol. 2014, 9, 28-36.

21. Dkhil, M.A. Role of berberine in ameliorating Schistosoma mansoni-induced hepatic injury in mice. Biol. Res. 2014, 47, 8. [CrossRef] [PubMed]

22. Küpeli, E.; Koşar, M.; Yeşilada, E.; Hüsnü, K.; Başer, C. A comparative study on the anti-inflammatory, antinociceptive and antipyretic effects of isoquinoline alkaloids from the roots of Turkish berberis species. Life Sci. 2002, 72, 645-657. [CrossRef]

23. Dkhil, M.A.; Al-Quraishy, S.; Al-Shamrany, A.; Alazzouni, A.S.; Lubbad, M.Y.; Al-Shaebi, E.M.; Taib, N.T. Protective effect of berberine chloride on Plasmodium chabaudi-induced hepatic tissue injury in mice. Saudi J. Biol. Sci. 2015, 22, 551-555. [CrossRef] [PubMed]

24. Vennerstrom, J.L.; Lovelace, J.K.; Waits, V.B.; Hanson, W.L.; Klayman, D.L. Berberine derivatives as anti-leishmanial drugs. Antimicrob. Agent Chemother. 2005, 34, 198-211.

25. Fata, A.; Rakhshandeh, H.; Berenji, F.; Jalalifard, A. Treatment of cutaneous leishmaniasis in murine model by alcoholic extract of Berberis vulgaris. Iran. J. Parasitol. 2006, 1, 39-42.

26. Imanshahidi, H.; Hosseinzadeh, H. Pharmacological and therapeutic effects of Berberis vulgaris and its active constituent, Berberine. Phytother. Res. 2008, 22, 999-1012. [CrossRef]

27. Abu-Reidah, I.M.; Ali-Shtayeh, M.S.; Jamous, R.M.; Arráez-Román, D.; Segura-Carretero, A. HPLC-DAD-ESI-MS/MS screening of bioactive components from Rhus coriaria L. (Sumac) fruits. Food Chem. 2015, 166, 179-191. [CrossRef] 
28. Lin, Y.M.; Anderson, H.; Flavin, M.T.; Pai, Y.H.S.; Greenwood, E.M.; Pengsuparp, T.; Pezzuto, J.M.; Schinazi, R.F.; Hughes, S.H.; Chen, F.C. In vitro anti-HIV activity of biflavanoids isolated from Rhus succedanea and Garcinia multiflora. J. Nat. Prod. 1997, 60, 884-888.

29. Gathirwa, J.W.; Rukunga, G.M.; Njagi, E.N.M.; Omar, S.A.; Mwitari, P.G.; Guantai, A.N.; Guantai, A.N.; Tolo, F.M.; Kimani, C.W.; Muthaura, C.N.; et al. The in vitro anti-plasmodial and in vivo anti-malarial efficacy of combinations of some medicinal plants used traditionally for treatment of malaria by the Meru community in Kenya. J. Ethnopharmacol. 2008, 115, 223-331. [CrossRef]

30. Ahmed, M.S.; Galal, A.M.; Ross, S.A.; Ferreira, D.; Elsohly, M.A.; Ibrahim, A.R.S.; Mossa, J.S.; El-Feraly, F.S. A weakly antimalarial biflavanone from Rhus retinorrhoea. Phytochemistry 2001, 58, 599-602. [CrossRef]

31. Gathirwa, J.W.; Rukunga, G.M.; Mwitari, P.G.; Mwikwabe, N.M.; Kimani, C.W.; Muthaura, C.N.; Kiboi, D.M.; Nyangacha, R.M.; Omar, S.A.; Rukunga, G.M. Traditional herbal antimalarial therapy in Kilifi district, Kenya. J. Ethnopharmacol. 2011, 134, 434-442. [CrossRef] [PubMed]

32. Pal Singh, M.; Gupta, A.; Sisodia, S. Gallic acid: Pharmacological promising lead molecule: A review. Inter. J. Pharm. Phyto. Resear. 2018, 10.

33. Gabr, S.A.; El-Metwally, M.M.; Al-Ghadir, A.H. Antioxidant and antibacterial active constituents of Rhus coriaria. Biotechnology 2014, 13, 37-45. [CrossRef]

34. Sequeda-Castañeda, L.G.; Muñoz-Realpe, C.C.; Celis-Zambrano, C.A.; Gutiérrez-Prieto, S.J.; Luengas-Caicedo, P.E.; Gamboa, F. Preliminary phytochemical analysis of Berberis goudotii Triana \& Planch. ex Wedd. (Berberidaceae) with anticariogenic and antiperiodontal activities. Sci. Pharm. 2019, 87, 2.

35. Wink, M. Medicinal plants: A source of anti-parasitic secondary metabolites. Molecules 2012, 17, 12771-12791. [CrossRef]

36. Le, T.B.; Beaufay, C.; Nghiem, D.T.; Mingeot-Leclercq, M.P.; Quetin-Leclercq, J.; Beaufay, C. In vitro anti-leishmanial activity of essential oils extracted from Vietnamese plants. Molecules 2017, 22, 1071. [CrossRef]

37. Andrade, M.A.; Azevedo, C.D.; Motta, F.N.; Santos, M.L.; Silva, C.L.; Santana, J.M.; Bastos, I.M. Essential oils: In vitro activity against Leishmania amazonensis, cytotoxicity and chemical composition. BMC Complement. Altern. Med. 2016, 16, 444. [CrossRef]

38. Colares, A.V.; Almeida-Souza, F.; Taniwaki, N.N.; Souza, C.; da Costa, J.G.; Calabrese, K.; Abreu-Silva, A.L. In vitro antileishmanial activity of essential oil of Vanillosmopsis arborea (Asteraceae) Baker. Evid. Based Complement. Alternat. Med. 2013, 2013, 727042. [CrossRef]

39. Le, T.B.; Beaufay, C.; Nghiem, D.T.; Pham, T.A.; Mingeot-Leclercq, M.P.; Quetin-Leclercq, J. Evaluation of the anti-trypanosomal activity of vietnamese essential oils, with emphasis on Curcuma longa L. and its components. Molecules 2019, 24, 1158. [CrossRef]

40. Gutiérrez, Y.I.; Scull, R.; Villa, A.; Satyal, P.; Cos, P.; Monzote, L.; Setzer, W.N. Chemical composition, antimicrobial and antiparasitic screening of the essential oil from Phania matricarioides (Spreng.) Griseb. Molecules 2019, 24, 1615. [CrossRef]

41. Sena-Lopes, Â.; Bezerra, F.S.B.; das Neves, R.N.; de Pinho, R.B.; Silva, M.T.O.; Savegnago, L.; Collares, T.; Seixas, F.; Begnini, K.; Henriques, J.A.P.; et al. Chemical composition, immunostimulatory, cytotoxic and antiparasitic activities of the essential oil from Brazilian red propolis. PLoS ONE 2018, 13, e0191797. [CrossRef]

42. Amelia, B.; Saepudin, E.; Cahyana, A.H.; Rahayu, D.U.; Sulistyoningrum, A.S.; Haib, J. GC-MS analysis of clove (Syzygium aromaticum) bud essential oil from Java and Manado. AIP Conf. Proc. 2017, 030082.

43. Nugraha, A.B.; Tuvshintulga, B.; Guswanto, A.; Tayebwa, D.S.; Rizk, M.A.; Gantuya, S.; Batiha, G.E.S.; Beshbishy, A.M.; Sivakumar, T.; Yokoyama, N.; et al. Screening the Medicines for Malaria Venture Pathogen Box against piroplasm parasites. Int. J. Parasitol. Drugs Drug Resist. 2019, 10, 84-90. [CrossRef] [PubMed]

44. Kosar, M.; Bozan, B.; Temelli, F.; Baser, K.H.C. Antioxidant activity and phenolic composition of sumac (Rhus coriaria L.) extracts. Food Chem. 2007, 103, 952-959. [CrossRef]

45. Islam, M.R.; Naima, J.; Proma, N.M.; Hussain, M.S.; Naim Uddin, S.M.; Hossain, M.K. In-vivo and in-vitro evaluation of pharmacological activities of Ardisia solanacea leaf extract. Clin. Phytosci. 2019, 5, 32. [CrossRef]

46. Kamble, S.S.; Gacche, N.R. Evaluation of anti-breast cancer, anti-angiogenic and antioxidant properties of selected medicinal plants. Euro. J. Integr. Med. 2019, 25, 13-19. [CrossRef]

47. Zhishen, J.; Mengcheng, T.; Jianming, W. The determination of flavonoid contents in mulberry and their scavenging effects on superoxide radicals. Food Chem. 1999, 64, 555-559. [CrossRef] 
48. Ma, X.K.; Li, X.F.; Zhang, J.Y.; Lei, J.; Li, W.W.; Wang, G. Analysis of the volatile components in Selaginella doederleinii by Headspace Solid Phase Micro extraction-Gas Chromatography-Mass Spectrometry. Molecules 2019, 25, 115. [CrossRef]

49. Tayebwa, D.S.; Tuvshintulga, B.; Guswanto, A.; Nugraha, A.B.; Batiha, G.E.S.; Gantuya, S.; Rizk, M.A.; Vudriko, P.; Sivakumar, T.; Yokoyama, N.; et al. The effects of nitidine chloride and camptothecin on the growth of Babesia and Theileria parasites. Ticks Tick. Borne Dis. 2018, 9, 1192-1201. [CrossRef]

50. Igarashi, I.; Suzuki, R.; Waki, S.; Tagawa, Y.I.; Seng, S.; Tum, S.; Omata, Y.; Saito, A.; Nagasawa, H.; Iwakura, Y.; et al. Roles of CD4+ T cells and gamma interferon in protective immunity against Babesia microti infection in mice. Infect. Immun. 1999, 67, 4143-4148. [CrossRef]

51. Beshbishy, A.M.; Batiha, G.E.S.; Yokoyama, N.; Igarashi, I. Ellagic acid microspheres restrict the growth of Babesia and Theileria in vitro and Babesia microti in vivo. Parasit. Vectors 2019, 12, 269. [CrossRef] [PubMed]

52. Beshbishy, A.M.; Batiha, G.E.S.; Adeyemi, O.S.; Yokoyama, N.; Igarashi, I. Inhibitory effects of methanolic Olea europaea and acetonic Acacia laeta on growth of Babesia and Theileria. Asia. Pac. J. Trop. Med. 2019, 12, 425-434.

53. Batiha, G.E.S.; Beshbishy, A.M.; Tayebwa, D.S.; Adeyemi, O.S.; Yokoyama, N.; Igarashi, I. Evaluation of the inhibitory effect of ivermectin on the growth of Babesia and Theileria parasites in vitro and in vivo. Trop. Med. Health 2019, 47, 42. [CrossRef] [PubMed]

54. Chou, T.C. Theoretical basis, experimental design, and computerized simulation of synergism and antagonism in drug combination studies. Pharmacol. Rev. 2006, 58, 621-681. [CrossRef]

Sample Availability: Not available.

(C) 2020 by the authors. Licensee MDPI, Basel, Switzerland. This article is an open access article distributed under the terms and conditions of the Creative Commons Attribution (CC BY) license (http://creativecommons.org/licenses/by/4.0/). 